\title{
PASSERINES FEEDING FROM FLOATING VEGETATION
}

MARTIN K. McNICHOLL, Beak Consultants Ltd., 3530 11A St. N.E., Calgary, Alberta T2E $6 \mathrm{M} 7$.

Recently Sealy reported several incidents of finches foraging from floating vegetation during autumn migration in Manitoba and Saskatchewan. ${ }^{6}$ He cited similar observations from Great Britain, and in North America both Sharp-tailed and Song Sparrows had been reported previously as feeding from floating vegetation (see Bent et al. 1968:805, 1532)." Madge also included two African passerines among birds using floating vegetation as a feeding platform in Zambia. ${ }^{3}$ Several additional observations, all from Manitoba, suggest that several passerines may use such temporary floating structures as vegetation and ice as feeding platforms not only in autumn migration, but also in spring and during the breeding season.

On 16 May 1967 I watched a Lincoln's Sparrow repeatedly run out from a stream bank on to floating stems of cattail (Typha sp.) in a ditch in the Delta Marsh, gleaning insects from the surface of the water on each foray. These observations lasted approximately 20 minutes and were repeated at the same location on the following two days.

During the breeding seasons of 1968 and 1969 I watched Yellowheaded Blackbirds of both sexes forage daily on floating rafts of Scirpus acutus on an open bay in Delta Marsh, which I named "Forster's Bay" after terns breeding there. ${ }^{4}$ The blackbirds spent periods of 15 to 30 minutes foraging in this manner throughout the day, and at least some individuals appeared to gather most of their food during these forays.
J.P. Goossen and I also have spring observations of warblers in Manitoba feeding from sheets of ice, and similar behaviour has been reported for waxwings in Alberta. ${ }^{2}{ }^{5}$

Thus, several passerines use temporarily available floating structures as feeding platforms. In addition, they may use such structures as perches for insect hawking, as indicated by Sealy's observation (pers. comm.) of an Eastern Phoebe apparently hawking insects from floating vegetation in backwater of the Assiniboine River in Winnipeg on 16 April 1976.

J.C. Barlow, Spencer Sealy and two anonymous referees made helpful suggestions on an earlier, longer version of this note. This constitutes Publication No. 24 of the University of Manitoba Field Station (Delta Marsh).

'BENT, A.C. and Collaborators (O.L. AUSTIN, JR., ed.). 1968. Life histories of North American cardinals, grosbeaks, buntings, towhees, finches, sparrows, and allies. U.S. Natl. Mus. Bull. 237.

${ }^{2}$ KERR, W.G. 1976. Bohemian Waxwing behavior. Calgary Field-Nat. 7:240.

${ }^{3}$ MADGE, S.G. 1972. Palaearctic wader migrants using floating vegetation as a feeding platform. Bird Study 19:172.

${ }^{4} \mathrm{McNICHOLL}, \mathrm{M} . K$. 1971. The breeding biology and ecology of Forster's Tern (Sterna forsteri) at Delta, Manitoba. M.Sc. Thesis, Univ. Manitoba, Winnipeg.

${ }^{5} \mathrm{McNICHOLL}$, M.K. and J.P. GOOSSEN. In press. Warblers feeding from ice. Wilson Bull.

${ }^{6}$ SEALY, S.G. 1977. Northern finches feeding from floating vegetation. Condor 79:278-279. 